\title{
Abiotic factors drives floristic variations of fern's metacommunity in an Atlantic Forest remnant
}

\author{
L. E. N. Costa ${ }^{a}$, R. P. Farias ${ }^{a}$, A. C. P. Santiago ${ }^{b}$, I. A. A. Silva ${ }^{c}$ and I. C. L. Barros \\ aPrograma de Pós-graduação em Biologia Vegetal, Universidade Federal de Pernambuco - UFPE, \\ Rua Prof. Nelson Chaves, Cidade Universitária, CEP 50670-420, Recife, PE, Brazil \\ ${ }^{\mathrm{b}}$ Centro Acadêmico de Vitória, Universidade Federal de Pernambuco - UFPE, Rua Alto do Reservatório, Bela Vista, \\ CEP 55608-680, Vitória de Santo Antão, PE, Brazil

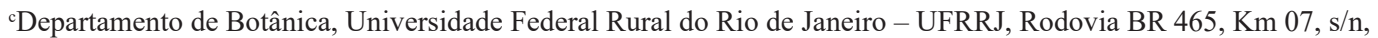 \\ Zona Rural, CEP 23890-000, Seropédica, RJ, Brazil \\ *e-mail: lucasbiologicasufpe@hotmail.com
}

Received: February 9, 2017 - Accepted: June 30, 2017 - Distributed: November 30, 2018

(With 2 figures)

\begin{abstract}
We analyzed floristic variations in fern's metacommunity at the local scale and their relationship with abiotic factors in an Atlantic Forest remnant of northeastern Brazil. Floristic and environmental variations were accessed on ten plots of $10 \times 20 \mathrm{~m}$. We performed cluster analyses, based on Bray-Curtis dissimilarity index to establish the floristic relationship. The influence of abiotic factors: luminosity, temperature, relative air humidity and relative soil moisture was evaluated from a redundancy analysis. We found 24 species belonging to 20 genera and 12 families. The fern's flora showed high floristic heterogeneity ( $>75 \%$ for most of the plot's associations). The fern's metacommunity was structured along an abiotic gradient modulated by temperature, luminosity, and relative soil moisture.
\end{abstract}

Keywords: floristic dissimilarity, species distribution, local scale, luminosity, "pteridophytes".

\section{Fatores abióticos regulam as variações florísticas na metacomunidade de samambaias em um remanescente de Floresta Atlântica}

\begin{abstract}
Resumo
Analisamos as variações florísticas na metacomunidade de samambaias em escala local e sua relação com fatores abióticos em um remanescente de Floresta Atlântica no Nordeste do Brasil. Variações florísticas e ambientais foram acessadas a partir de dez parcelas de $10 \times 20 \mathrm{~m}$. Realizamos análises de cluster, baseado no índice de similaridade de Bray-Curtis para estabelecer relações florísticas. A influência de fatores abióticos: luminosidade, temperatura, umidade relativa do ar e umidade relativa do solo foram avaliadas a partir da análise de redundância. Encontramos 24 espécies pertencentes a 20 gêneros e 12 famílias. A flora de samambaias exibiu uma elevada heterogeneidade florística ( $>75 \%$ para a maioria das associações entre plots). Observou-se que a metacomunidade de samambaias estava estruturada ao longo de um gradiente abiótico modulado pela temperatura, luminosidade e umidade relativa do solo.
\end{abstract}

Palavras-chave: dissimilariade florística, distribuição de espécies, escala local, luminosidade, "pteridófitas".

\section{Introduction}

The metacommunity represents a group of species that potentially interact and that are spatially segregated into distinct patches connected by dispersal (Wilson, 1992). This concept highlights the importance of spatial scale affecting the role of the process that structures communities (Leibold et al., 2004). However, metacommunities have no clear boundaries, and different species respond and adapt across scales (Leibold et al., 2004).

At the local scale, the variations in species composition are often related to heterogeneity of environmental factors in space (Pyke et al., 2001; Zuquim et al., 2007).
Specifically in tropical forests, the edaphic factors, luminosity, and water availability are associated with floristic dissimilarities across habitats (Tuomisto and Poulsen, 1996). Floristic variations may also be explained by historical factors, random dispersal or limitations species dispersal (Hubbell, 2001). Considering microhabitats, the floristic composition of metacommunities can be related to processes as patch-dynamic, which all patches are ecologically equaled and with dispersion playing the major role, or to species sorting from environmental gradients and niche (Leibold et al., 2004). 
The distribution of tropical plant species has been intensely altered because of environmental degradation resulting in the creation of forests with new dynamics. Typically, tropical forests have become smaller and isolated, consequently, the dynamic of communities at local scale changes by a loss in the complexity of vegetation and biotic and abiotic homogenization (Murcia, 1995; Laurance, 1999; Lôbo et al., 2011). Unfortunately, this is a reality for Brazilian Atlantic Forest, intensively and widely deforested, remaining only about $8 \%$ of original cover, represented mostly small and isolated forests (Myers et al., 2000; Ribeiro et al., 2009), being one of the worst scenarios recorded in the northeast region.

In this sense, the aim of this study was to analyses the floristic variations in fern's metacommunity and their relationship with abiotic factors in an Atlantic Forest remnant of northeastern Brazil. Ferns offer several advantages as a focal community because variations in species composition are often related to environmental heterogeneity (e.g. Tuomisto and Poulsen, 1996; Tuomisto et al., 2003). In addition, the high ability of airborne ferns' spores indicates no dispersal limitation in terms of local distribution (Zobel et al., 2002).

\section{Material and Methods}

\subsection{Study area}

The study was carried out in an Atlantic Forest remnant with Lowland Rain Forest vegetation (470 ha) surrounded by sugar cane matrix, situated in the district of Rio Formoso, Pernambuco, Northeastern of Brazil (8³8'58” S, 35॰10’21" W, maximum: $100 \mathrm{~m}$ a.s.1.). According to Peel et al. (2007), the region presents hot and wet climate. The average annual temperature is $25.2{ }^{\circ} \mathrm{C}$ and the average annual rainfall is approximately $2300 \mathrm{~mm}$. The short dry season is from October-December, with rainfall under $60 \mathrm{~mm}$ (Instituto de Tecnologia de Pernambuco, 2010).

\subsection{Data collection}

The fern community at the Atlantic forest of northeast of Brazil is spatially structured from specific microhabitats or "preferential habitats" (Ambrósio and Barros, 1997; Pereira et al., 2014). We walked the entire fragment and based on preferential habitats, delimited ten plots $(10 \times 20 \mathrm{~m})$ that were at least $40 \mathrm{~m}$ apart from each other. Each plot was characterized according to the luminosity, measured with a light meter, as well as, the temperature, the relative air humidity, and the relative soil moisture, measured with a thermohygrometer (Table 1). Additionally, the plots were identified according to their occurrence in the interior or edge forest. We considered as edge forest the first $40 \mathrm{~m}$ of forest from the forest-matrix boundary (Silva et al., 2011).

The plot survey was carried out in June and July 2013 included all terrestrial ferns and epiphytes fixed until $2 \mathrm{~m}$ in phorophytes. For species identification, we utilized identification keys and specialized literature (e.g. Tryon and Tryon, 1982; Salino and Almeida, 2015). The species nomenclature was consulted from database Tropicos (2017), of Missouri Botanical Garden. The specimens were deposited in the Herbário UFP- Geraldo Mariz.

\subsection{Data analyses}

We calculated the Bray-Curtis index between plots to cluster analyses, using unweighted pair group method with arithmetic mean (UPGMA). A Multi-Response Permutation Procedure (MRPP) was carried out to test whether the groups were significant and not explained by chance. The Indicator Species Analysis (ISA) was performed to detect indicators species, with statistical significance assessed via Monte Carlo test, 1000 randomizations. We considered robust an indicator value (IndVal) $\geq 25 \%$ (Dufrêne and Legendre, 1997). A redundancy analysis (RDA) using linear combination "LC" scores was performed to evaluate the relationship between floristic variations and abiotic factors. The significance of RDA axis was tested applying Monte Carlo randomizations (1000). For all statistical analyses $\mathrm{p}$ values $\leq 0.05$ were considered significant. The analyses were carried out in Fitopac 2.1 (Shepherd, 2010) and Pcord 4.0 (McCune and Mefford, 1999).

Table 1. Plots description and environmental conditions of ten plots established along a Lowland Atlantic Forest remnant in Northeaster of Brazil.

\begin{tabular}{ccccccc}
\hline PLOTS & MICROHABITAT & SITE OF OCCURRENCE & T $\left({ }^{\circ} \mathbf{C}\right)$ & RSM (\%) & RAH (\%) & L (LIGHT) \\
\hline P1 & banks of a brook & Interior Forest & 27.5 & 80 & 74 & 155 \\
P2 & rocky outcrops & Interior Forest & 27 & 63 & 74 & 253 \\
P3 & low declivity area & Edge Forest & 31.3 & 53 & 70 & 1930 \\
P4 & Natural gap & Interior Forest & 27.1 & 66 & 70 & 682 \\
P5 & Marsh & Interior Forest & 29.3 & 67 & 76 & 313 \\
P6 & Slope area & Interior Forest & 28.2 & 69 & 65 & 210 \\
P7 & low declivity area & Edge Forest & 31 & 64 & 74 & 652 \\
P8 & low declivity area & Edge Forest & 29.8 & 46 & 69 & 1414 \\
P9 & Inundated area & Edge Forest & 27.5 & 75 & 60 & 1330 \\
P10 & Marsh & Interior Forest & 29.8 & 60 & 76 & 613 \\
\hline
\end{tabular}

$\mathrm{T}=$ temperature; $\mathrm{RSM}=$ Relative soil moisture; $\mathrm{RAH}=$ Relative air humidity; $\mathrm{L}=$ luminosity . 


\section{Results}

We found 24 fern's species belonging to 20 genera and 12 families (Table 2). The floristic composition showed high dissimilarities with most of the associations $\geq 75 \%$ of dissimilarity (i.e. 38 of 45 associations). Cluster analyses revealed the formation of one floristic group, two pairs of plots and one ungrouped plot (Figure 1). The MRPP identified two floristic groups (group 1: 3, 4, 7, 8 and 10; group 2: 1, 2, 5 and 9), both true and not explained by chance $(p=0.009)$. Moreover, the groups were weakly isolated on florist multivariate space $(\mathrm{T}=-3.46 ; \mathrm{p}=0.009)$ with high heterogeneity within and between the groups $(\mathrm{A}=0.43 ; \mathrm{p}=0.009)$. Only Neoblechnum brasiliense was identified as indicator species, with high specificity and fidelity for group 1 (IndVal $=99.6 ; \mathrm{p}=0.042)$.

The RDA showed $86.63 \%$ of total cumulative variance explained in the two first axis: $53.38 \%$ and $33.25 \%$ for the first and second axis, respectively (Figure 2), both significative $(\mathrm{p}=0.0100)$. The first axis was positively correlated with relative soil moisture $(0.873)$, and negatively with luminosity (-0.819) and temperature (-0.837). The second axis was negatively correlated with relative

Table 2. List of ferns species surveyed in 10 plots in a Lowland Atlantic Forest Remnant in the Northeast of Brazil (Pernambuco, Brazil).

\begin{tabular}{|c|c|c|c|c|c|c|c|c|c|c|}
\hline \multirow{2}{*}{ Family/ Species } & \multicolumn{10}{|c|}{ Species Abundance per plot } \\
\hline & 1 & 2 & 3 & 4 & 5 & 6 & 7 & 8 & 9 & 10 \\
\hline \multicolumn{11}{|l|}{ Anemiaceae } \\
\hline Anemia hirta (L.) Sw. & - & - & - & 2 & - & - & - & - & 9 & 1 \\
\hline \multicolumn{11}{|l|}{ Aspleniaceae } \\
\hline Asplenium serratum L. & - & 3 & - & - & - & - & - & - & - & - \\
\hline \multicolumn{11}{|l|}{ Blechnaceae } \\
\hline Neoblechnum brasiliense (Desv.) Gasper \& V.A.O Dittrich & - & - & 96 & 15 & - & - & 38 & 56 & 1 & 6 \\
\hline Blechnum occidentale L. & 1 & - & - & 24 & - & 2 & 3 & - & - & 22 \\
\hline \multicolumn{11}{|l|}{ Cyatheaceae } \\
\hline Cyathea microdonta (Desv.) Domin. & - & - & - & 8 & - & - & - & 3 & 10 & 2 \\
\hline Cyathea phalerata Mart. & 7 & - & - & - & 5 & - & - & - & - & - \\
\hline \multicolumn{11}{|l|}{ Dennstaedtiaceae } \\
\hline Hypolepis repens (L.) C. Presl. & - & 4 & 5 & - & - & - & - & - & - & - \\
\hline \multicolumn{11}{|l|}{ Dryopteridaceae } \\
\hline Ctenitis falciculata (Raddi) Ching. & 14 & 5 & - & - & - & - & - & - & - & - \\
\hline Ctenitis paranaensis (C.Chr.) Lellinger & 2 & - & - & - & 4 & - & - & - & - & - \\
\hline Cyclodium heterodon (Schrad.) T. Moore. & - & - & - & - & - & 11 & - & - & - & - \\
\hline Megalastrum eugenii (Brade) A.R. Sm. \& R.C. Moran. & 1 & 6 & - & - & - & - & - & - & - & - \\
\hline \multicolumn{11}{|l|}{ Hymenophyllaceae } \\
\hline Didymoglossum kraussii Hook. & - & 20 & - & - & - & - & - & - & - & - \\
\hline \multicolumn{11}{|l|}{ Lygodiaceae } \\
\hline *Lygodium venustum $\mathrm{Sw}$. & - & - & - & - & - & - & - & - & 3 & - \\
\hline *Lygodium volubile $\mathrm{Sw}$. & - & - & 7 & - & - & - & - & - & 2 & 1 \\
\hline \multicolumn{11}{|l|}{ Marattiaceae } \\
\hline Danaea geniculata Raddi. & 32 & - & - & - & - & - & - & - & - & - \\
\hline \multicolumn{11}{|l|}{ Pteridaceae } \\
\hline Adiantum latifolium Lam. & - & - & - & 3 & 4 & - & - & - & 24 & - \\
\hline Adiantum petiolatum Desv. & - & - & 5 & - & - & 1 & - & 14 & - & - \\
\hline *Anetium citrifolium (L.) Splitg. & 2 & 2 & - & 3 & - & - & - & - & - & 6 \\
\hline Pityrogramma calomelanos (L.) Link. & - & - & 15 & 6 & 1 & 1 & - & 14 & - & 2 \\
\hline \multicolumn{11}{|l|}{ Tectariaceae } \\
\hline Tectaria incisa Cav. & - & 6 & - & 7 & 7 & - & 29 & 108 & - & 43 \\
\hline \multicolumn{11}{|l|}{ Telypteridaceae } \\
\hline Goniopteris abrupta (Desv.). A.R.Sm. & 17 & - & - & - & 6 & - & 4 & - & 8 & 4 \\
\hline Christella hispidula (Decne.) Holttum & - & - & - & - & - & - & 10 & - & - & - \\
\hline Steiropteris polypoidioides (Raddi) Salino \& T.E Almeida & 6 & 5 & - & - & - & - & - & - & - & - \\
\hline Meniscium serratum (Cav.) & - & - & 20 & - & - & - & - & 2 & 1 & - \\
\hline
\end{tabular}

* Epiphytes. 


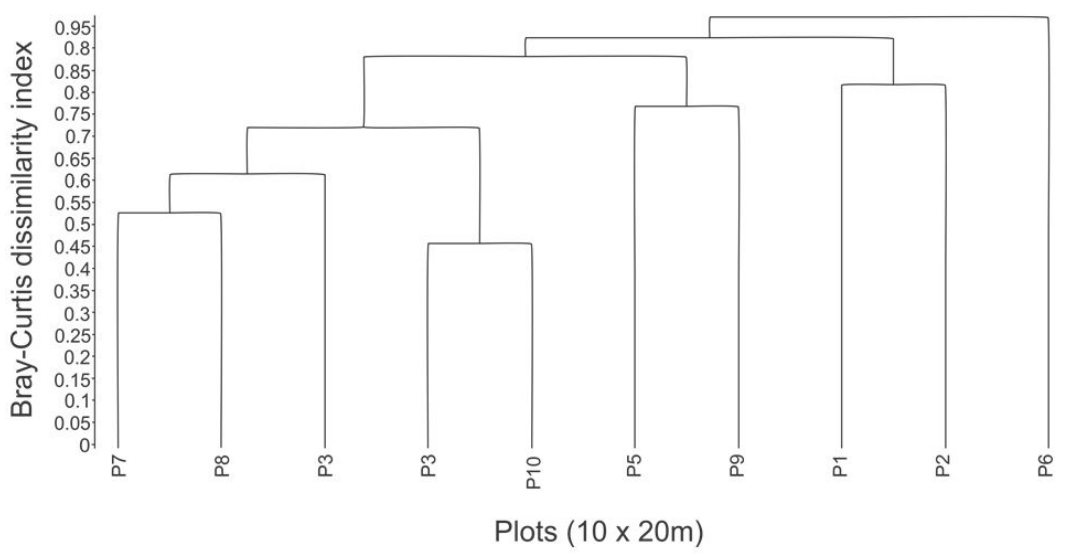

Figure 1. Similarity tree (Bray-Curtis' coefficient) obtained by cluster analysis (UPGMA) from 10 plots surveyed in a Lowland Atlantic Forest Remnant in the Northeast of Brazil (Pernambuco, Brazil). Cophenetic correlation =0.8649.

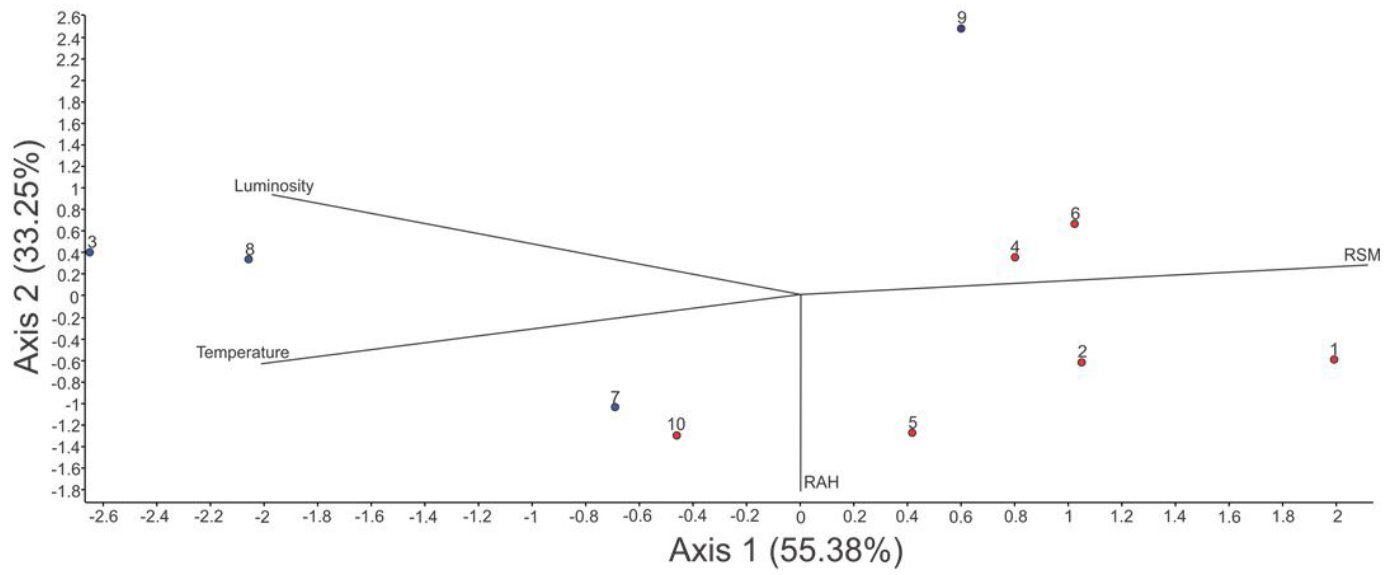

Figure 2. Ordination diagram of the first two axes of Redundancy Analysis for the fern's flora of 10 plots surveyed in a Lowland Atlantic Forest Remnant in the Northeast of Brazil (Pernambuco, Brazil). RSM= Relative soil moisture; RAH= Relative air humidity. Blue circles indicate edge forest and red circles interior forest.

air humidity (-0.976). This results indicated the presence of an abiotic gradient, represented in the first part by sites with high luminosity and temperature and low relative soil moisture (plots 3, 7 and 8), and in the second part for shaded sites, with high relative air humidity and high relative soil moisture (Figure 2).

\section{Discussion}

Our data support a strong floristic dissimilarity pattern for ferns at a local scale. The species richness data of the study area denotes that an accentuated floristic variation occurs even with few species (see Pereira et al., 2013 to access information about species richness in northeastern Atlantic Forest). Therefore, this pattern does not seem to be related to species richness.

The floristic variation in ferns' metacommunity at local scale drove by abiotic factors has been indicated for other herbaceous groups or tree species in tropical forests (Poulsen et al., 2006; John et al., 2007). Specifically for ferns, abiotic factors as water availability and shading are key-factors affecting ecological patterns (Ferrer-Castán and Vetaas, 2005; Karst et al., 2005). These factors are directly related to the biology of ferns for both the gametophyte and sporophyte phases (Windisch, 1990). The higher water availability and lower luminosity certainly favor spore germination and the establishment of gametophytes (Page, 2002). Additionally, these factors are fundamental for the physiological maintenance of the sporophytes, which typically has low evaporative control and high intolerance to abiotic fluctuations (Page, 2002). Therefore, even ferns being a group with high ability of airborne, the establishment of individuals and species distribution does not occur from a random pattern.

The species $N$. brasiliense was an indicator of areas with low water availability as edge plots, with low abundances or absences in water-saturated plots. This fern is widely distributed in the Brazilian Atlantic forest, occurring in several habitat types (Dittrich, 2005). The high abundance values 
observed seems to be the result of vegetative propagation that can be favored by edge conditions (Murcia, 1995), and is typically recorded in the Blechnaceae family (Dittrich, 2005). Indeed, edges can favor species dominance (Murcia, 1995), even for some ferns species (e.g. Silva et al., 2011).

We showed that ferns' metacommunity has an accentuated floristic variation at the local scale, which was modulated by an environmental gradient, despite the low species richness of the forest remnant.

\section{Acknowledgements}

The authors would like to thank Dr. Nivea Dias do Santos for help in statistical analysis; National Council for Scientific and Technological Development (CNPq) for providing research assistantships; and the Trapiche Mill, for allowing and supporting the development of this study. In addition, we thank the two anonymous referee for their useful suggestions.

\section{References}

AMBRÓSIO, S.T. and BARROS, I.C.L., 1997. Pteridófitas de uma área remanescente de Floresta Atlântica do Estado de Pernambuco, Brasil. Acta Botanica Brasílica, vol. 11, no. 2, pp. 105-113. http://dx.doi.org/10.1590/S0102-33061997000200002.

DITTRICH, V.A.O., 2005. Estudos Taxonômicos no Gênero Blechnum L. (Pterophyta: Blechnaceae) para as regiões Sudeste e Sul do Brasil. Rio Claro: Universidade Estadual Paulista, 223 p. Tese de Doutorado em Ciências Biológicas (Biologia Vegetal).

DUFRÊNE, M. and LEGENDRE, P., 1997. Species assemblages and indicator species: the need for a flexible asymmetrical approach. Ecological Monographs, vol. 67, no. 3, pp. 345-366. http://dx.doi. org/10.1890/0012-9615(1997)067[0345:SAAIST]2.0.CO;2.

FERRER-CASTÁN, D. and VETAAS, O.R., 2005. Pteridophyte richness, climate and topography in the Iberian Peninsula: comparing spatial and nonspatial models of richness patterns. Global Ecology and Biogeography, vol. 14, no. 2, pp. 155-165. http://dx.doi.org/10.1111/j.1466-822X.2004.00140.x.

HUBBELL, S.P. 2001. The unified theory of biogeography and biodiversity. 1st ed. Princeton: University Press, 392 p. Monographys in Population Biology.

INSTITUTO DE TECNOLOGIA DE PERNAMBUCO - ITEP. Laboratório de Meteorologia de Pernambuco - LAMEPE, 2010 [viewed 20 December 2013]. [online]. Available from: http:// www.itep.br/meteorologia/lamepe

JOHN, R., DALLING, J.W., HARMS, K.E., YAVITT, J.B., STALLARD, R.F., MIRABELLO, M., HUBBELL, S.P., VALENCIA, R., NAVARRETE, H., VALLEJO, M. and FOSTER, R.B., 2007. Soil nutrients influence spatial distributions of tropical tree species. Proceedings of the National Academy of Sciences of the United States of America, vol. 104, no. 3, pp. 864-869. PMid:17215353. http://dx.doi.org/10.1073/pnas.0604666104.

KARST, J., GILBERT, B. and LECHOWICZ, M.J., 2005. Fern community assembly: the roles of chance and the environment at local and intermediate scales. Ecology, vol. 86, no. 9, pp. 24732486. http://dx.doi.org/10.1890/04-1420.
LAURANCE, W.F., 1999. Reflections on the tropical deforestation crisis. Biological Conservation, vol. 91, no. 2-3, pp. 109-117. http://dx.doi.org/10.1016/S0006-3207(99)00088-9.

LEIBOLD,M.A.,HOLYOAK,M.,MOUQUET,N.,AMARASEKARE, P., CHASE, J.M., HOOPES, M.F., HOLT, R.D., SHURIN, J.B., LAW, R., TILMAN, D., LOREAU, M. and GONZALEZ, A., 2004. The metacommunity concept: a framework for multi-scale community ecology. Ecology Letters, vol. 7, no. 7, pp. 601-613. http://dx.doi.org/10.1111/j.1461-0248.2004.00608.x.

LÔBO, D., LEÃO, T., MELO, F.P.L., SANTOS, A.M.M. and TABARELLI, M., 2011. Forest fragmentation drives Atlantic forest of northeastern Brazil to biotic homogenization. Diversity \& Distributions, vol. 17, no. 2, pp. 287-296. http://dx.doi. org/10.1111/j.1472-4642.2010.00739.x.

MCCUNE, B. and MEFFORD, M.J. 1999. PC-ORD: multivariate analysis of ecological data; Version 4 for Windows: user's guide. Oregon: MjM Software Design.

MURCIA, C., 1995. Edge effects in fragmented forests: implications for conservation. Trends in Ecology \& Evolution, vol. 10, no. 2, pp. 58-62. PMid:21236953. http://dx.doi.org/10.1016/S01695347(00)88977-6.

MYERS, N., MITTERMEIER, R.A., MITTERMEIER, C.G., DA FONSECA, G.A.B. and KENT, J., 2000. Biodiversity hotspots for conservation priorities. Nature, vol. 403, no. 6772, pp. 853-858. PMid:10706275. http://dx.doi.org/10.1038/35002501.

PAGE, C.N., 2002. Ecological strategies in fern evolution: a neopteridological overview. Review of Palaeobotany and Palynology, vol. 119, no. 1-2, pp. 1-33. http://dx.doi.org/10.1016/ S0034-6667(01)00127-0.

PEEL, M.C., FINLAYSON, B.L. and MCMAHON, T.A., 2007. Updated world map of the Koppen-Geiger climate classification. Hydrology and Earth System Sciences, vol. 11, no. 5, pp. 16331644. http://dx.doi.org/10.5194/hess-11-1633-2007.

PEREIRA, A.F.N., SILVA, I.A.A., SANTIAGO, A.C.P. and BARROS, I.C.L., 2013. Richness, geographic distribution and ecological aspects of the fern community within the Murici Ecological Station in the state of Alagoas, Brazil. Acta Botanica Brasílica, vol. 27, no. 4, pp. 788-800. http://dx.doi.org/10.1590/ S0102-33062013000400019.

PEREIRA, A.F.N., SILVA, I.A.A., SANTIAGO, A.C.P. and BARROS, I.C.L., 2014. Efeito de borda sobre a comunidade de samambaias em fragmento de Floresta Atlântica (Bonito, Pernambuco, Brasil). Interciência, vol. 39, no. 4, pp. 281-287. http://dx.doi.org/0378-1844/14/04/281-07

POULSEN, A.D., TUOMISTO, H. and BALSLEV, H., 2006. Edaphic and floristic variation a 1-ha plot of lowland Amazonian rain forest. Biotropica, vol. 38, no. 4, pp. 468-478. http://dx.doi. org/10.1111/j.1744-7429.2006.00168.x.

PYKE, C.R., CONDIT, R., AGUILAR, S. and LAO, S., 2001. Floristic composition across a climatic gradient in a neotropical lowland forest. Journal of Vegetation Science, vol. 12, no. 4, pp. 553-566. http://dx.doi.org/10.2307/3237007.

RIBEIRO, M.C., METZGER, J.P., MARTENSEN, A.C., PONZONI, F.J. and HIROTA, M.M., 2009. The Brazilian Atlantic Forest: how much is left, and how is the remaining forest distributed? Implications for conservation. Biological Conservation, vol. 142, no. 6, pp. 1141-1153. http://dx.doi.org/10.1016/j.biocon.2009.02.021. 
SALINO, A. and ALMEIDA, T.E., 2015. Thelypteridaceae in lista de espécies da flora do Brasil. Rio de Janeiro: Jardim Botânico do Rio de Janeiro.

SHEPHERD, G.J. 2010. FITOPAC version 2.0. Campinas: UNICAMP.

SILVA, I.A.A., PEREIRA, A.F.N. and BARROS, I.C.L., 2011. Edge effects on fern community in an Atlantic Forest remnant of Rio Formoso, PE, Brazil. Brazilian Journal of Biology = Revista Brasileira de Biologia, vol. 71, no. 2, pp. 421-430. PMid:21755159. http://dx.doi.org/10.1590/S1519-69842011000300011.

TROPICOS, 2017 [viewed 20 January 2017]. [online]. Available from: http://www.tropicos.org/

TRYON, R.M. and TRYON, A.F., 1982. Ferns and allied plants with special reference to Tropical America. New York: Springer-Verlag.

TUOMISTO, H. and POULSEN, A.D., 1996. Influence of edaphic specialization on pteridophyte distribution in neotropical rain forests. Journal of Biogeography, vol. 23, no. 3, pp. 283-293. http://dx.doi.org/10.1046/j.1365-2699.1996.00044.x.
TUOMISTO, H., RUOKOLAINEN, K. and YLI-HALLA, M., 2003. Dispersal, environment and floristic variation of western Amazon forests. Science, vol. 299, no. 5604, pp. 241-244. PMid:12522248. http://dx.doi.org/10.1126/science.1078037.

WILSON, D.S., 1992. Complex interactions in metacommunities, with implications for biodiversity and higher levels of selection. Ecology, vol. 73, no. 6, pp. 1984-2000. http://dx.doi.org/10.2307/1941449.

WINDISCH, P.G., 1990. Pteridófitas da região Norte-ocidental do Estado de São Paulo: guia para estudo e excursões. São José do Rio Preto: UNESP.

ZOBEL, M., OTSUS, M., LIIRA, J., MOORA, M. and MOLS, T., 2002. Is small-scale species richness limited by seed availability or microsite availability? Ecology, vol. 81, no. 12, pp. 32743282. http://dx.doi.org/10.1890/0012-9658(2000)081[3274:IS SSRL]2.0.CO;2.

ZUQUIM, G., COSTA, F.R.C. and PRADO, J., 2007. Fatores que determinam a distribuição de espécies de pteridófitas da Amazônia Central. Revista Brasileira de Biociências, vol. 5, no. 2 , pp. 360-362. 